\title{
Effect of different sources and levels of some dietary biological additives on: IV- immunity and haematology of Nile Tilapia, Oreochromis niloticus
}

\author{
Abdelhamid, A. Mohamed ${ }^{1}$; Refaey, M. M. Ali' ${ }^{1}$, Seden, M. E. Abdelfatah ${ }^{2}$ and \\ Osama A.Zenhom ${ }^{2}$ \\ 1- Anim. Prod. Dept., Fac. of Agric., Mansoura Univ., Mansoura, Egypt. \\ 2- Cent. Lab. For Aqua. Res., Abbasa, Abo-Hammad, Egypt.
}

\section{ABSTRACT}

This study aimed to investigate the effect of dietary graded levels of three preand probiotics on the immunity and haematology of all-males mono-sex Nile tilapia fish. The experimental period was 16 weeks after 2 weeks adaptation period. In the pathogenicity test, dietary inclusion of Aqua Superzyme at $0.01 \%$ of the diet, Garlen Allicin at $0.01 \%$ of the diet, and Diamond V (XPC) at $0.5 \%$ of the diet, generally reduced the mortality rate (\%) and therefore increased the survival rate (\%). Yet, the only significant $(\mathrm{P}<0.05)$ positive effect was due to Aqua Superzyme at $0.01 \%$ of the diet in general and after 48h whereas the other supplements did not significantly ( $\mathrm{P}>0.05)$ affect the pathogenicity. The comparisons among substances and their levels clear that the best survival was occurred in the treatment 1:1, i.e the fish group fed Aqua Superzyme (at $0.01 \%$ of the diet) diet. The haematological parameters' values increased significantly $(\mathrm{P}<0.05)$ by using Aqua Superzyme, particularly at $0.01 \%$ of the diet; Garlen Allicin, particularly at $0.01 \%$ of the diet; and Diamond V (Original XPC), particularly at $0.4 \%$ of the diet). Yet, the overall significantly $(\mathrm{P}<0.05)$ best valus for all tested parameters among additives and their levels was that contained Aqua Superzyme at $0.02 \%$ of the diet. So, it is recommended to supply Nile tilapia's diet with the prebiotic Aqua Superzyme at $0.01-0.02 \%$ of the diet to improve the immunity system of the fish.

Keywords: Nile tilapia, pathogenicity, haematology (Hb, RBCs, PCV\% and WBCs).

\section{INTRODUCTION}

Antibiotics have been used for many years as growth promoting agents in addition to their antipathogenic bacterial function which reduce growth and feed conversion. These growth promoters were linked to emergence of multiple drug resistant bacteria and antibiotic residues in animal products (Wary and Davies, 2000). Therefore, using natural feed additives to substitute antibiotics has become an area of great interest (Kumar et al., 2003).

Probiotics, unlike antibiotics, imply the use of live micro-organism rather than specific products of their metabolism. Probiotics, which means for life in Greek (Gibson and Fuller, 2000) has been defined as a live microbial feed supplement, which beneficially affects the host animal by improving its intestinal microbial balance. The mechanism of probiotic effect on animal health was conclusively reviewed by Patterson and Burkholder (2003). They reported that probiotics enable the host animal to return to animal state competition for substrates, production of compounds that inhibit pathogenes, and competition for attachment sites. Results showed that dietary supplementation of $B$. subtilis at a dose of $1.35 \times 10^{7} \mathrm{cfu} \mathrm{g}^{-1}$ improved non-specific immune responses and disease resistance of juvenile large yellow croaker, L. crocea (Ai et al., 2011). The present investigation aimed to study 
the effect of dietary graded levels of three pre-and probiotics on the immunity and haematology of all-males mono-sex Nile tilapia fish.

\section{MATERIALS AND METHODS}

All the experimental conditions, diets, and facilities were as mentioned before in Abdelhamid et al. (2013). The $1^{\text {st }}$ and $2^{\text {nd }}$ additives used were the prebiotic Aqua Superzyme and the probiotic Garlen Allicin, each at $0.01,0.02$, and $0.03 \%$ of the diet. The $3^{\text {rd }}$ additive used was the probiotic Diamond V-Original XPC at $0.4,0.5$, and $0.6 \%$ of the diet, besides the control without additives.

\section{Pathogenicity:}

After 16 weeks of feeding on experimental diets, the fish of each experimental group were divided into two subgroups, each containing 10 fish and were placed into $150 \mathrm{~L}$ tank each. The feeding rate was 3\% of biomass per day during the 10 days trail. The challenge experiment was carried out using the strain Aeromonas hydrophila isolated previously in the laboratory of fish disease Department, Central Laboratory for Aquaculture Research, Abbassa, Abou-Hammad, Sharkia, Egypt, The first subgroup was challenged intraperitoneally (IP) with pathogenic Aeromonas hydrophila $\left(0.2 \mathrm{ml}\right.$ of $\left.5 \times 10^{5} \mathrm{CFU} / \mathrm{ml}\right)$. The second subgroup was injected IP with $0.2 \mathrm{ml}$ of saline solution as a control. Both subgroups were kept under observation for 10 days to record the daily mortality rate as described by Schaperclacus et al., (1992). All the experimental infected fish were daily noted for any abnormal clinical signs and mortalities. The dead and clinically diseased fish were subject to bacterial reisolation.

\section{Haematology:}

At the end of the experimental period, 10 fish from each of the treatments and control group were taken for physiological investigations. Fish were not fed for $24 \mathrm{~h}$ prior to blood sampling. Fish were anaesthetized using buffered tricaine methane sulfonate (20 mg /L) and blood was collected from fish caudal vein by a sterile syringe. Blood samples were transferred into dry and clean tube with EDTA solution for measuring hemoglobin (Hb), red blood cells (RBCs), and hematocrite (PCV\%) in blood after good mixing.

Total erythrocytic were performed simultaneously using the improved neubauer chamber and Natt \& Herrick, solution as diluting fluid according to the method described by Natt and Herrick (1952), where the total number of red cells in five secondary squares were determined and multiplied by 10,000. This value represents the total number of erythrocytes per cubic millimeter of blood.

Number of erythrocytes $/ \mathrm{mm}^{3}=(\mathrm{N}$ x 200 x 400 x10)/80, where:

$\mathrm{N}=$ Number of erythrocytic cells counted in 80 small squares

$200=$ Dilution factor

$400=$ Area of each small squares (tertiary squares)

$80=$ Number of small squares (tertiary).

For determination of hemoglobin $(\mathrm{Hb})$ the blood was treated with a reagent containing potassium ferricyanide, potassium cyanide and potassium dihydrogen phosphate. The ferricyanide reacts with blood forms methoglobin which was converted to cyanomethemoglobin by cyanide. The color obtained was measured spectrophotometerically at wave length $546 \mathrm{~nm}$ according to the method described by Stoskopf (1993). Concentration of blood heamoglobin was calculated from the following equation:

Blood heamoglobin concentration $=\mathrm{A} \times 36.8=\mathrm{g} / \mathrm{dl}$, Where: 
A = Absorbance of sample.

The packed cell volume (haematocrite \%) was measured using the microhaematocrit method (Schalm, 1975). The volume of the red cells as a percentage of the total volume of the blood was recorded as PCV\%.

Statistical analysis:

Data obtained were analyzed using one-way analysis of variance which was performed according to SAS (2006). Differences were subjected to Duncan's (1955) multible range test.

\section{RESULTS AND DISCUSSION}

\section{Immunity (pathogenicity against Aeromonas hydrophila):}

In the pathogenicity test, dietary inclusion of Aqua Superzyme $\left(\mathrm{A}_{1}\right)$, Garlen Allicin $\left(\mathrm{G}_{1}\right)$, and Diamond V $\left(\mathrm{XPC}_{2}\right)$, (Tables 1,2 , and 3, respectively) generally reduced the mortality rate (\%) and therefore increased the survival rate (\%). Yet, the only significant $(\mathrm{P} \leq 0.05)$ positive effect was due to $\mathrm{A}_{1}$ in general and after $48 \mathrm{~h}$ (Table 1) whereas the other supplements (Tables 2 and 3 ) did not significantly ( $\mathrm{P} \geq$ $0.05)$ affect. The comparisons among substances and their levels clear that the best survival was occurred in the treatment $1 * 1$, i.e the fish group fed Aqua Superzyme (at $0.01 \%$ of the diet) diet (Table 4 ).

Table 1: Bacterial challenge test (pathogenicity, \%) of O. niloticus fed the Aqua Superzyme experimental diets.

\begin{tabular}{|c|c|c|c|c|}
\hline Treat. & Mortality $_{\mathbf{2 4}}$ & Mortality $_{\mathbf{4 8}}$ & Mortality & Survival \\
\hline Control & $80.0^{\mathrm{ab}}$ & $0.0^{\mathrm{b}}$ & $80.0^{\mathrm{ab}}$ & $20.0^{\mathrm{bc}}$ \\
\hline $\mathbf{A}_{\mathbf{1}}$ & $60.0^{\mathrm{bc}}$ & $0.0^{\mathrm{b}}$ & $60.0^{\mathrm{c}}$ & $40.0^{\mathrm{a}}$ \\
\hline $\mathbf{A}_{\mathbf{2}}$ & $53.33^{\mathrm{c}}$ & $13.33^{\mathrm{a}}$ & $66.66^{\mathrm{bc}}$ & $33.34^{\mathrm{ab}}$ \\
\hline $\mathbf{A}_{\mathbf{3}}$ & $86.67^{\mathrm{a}}$ & $0.0^{\mathrm{b}}$ & $86.66^{\mathrm{a}}$ & $13.34^{\mathrm{c}}$ \\
\hline $\mathbf{P}>\mathbf{F}$ & 0.039 & 0.052 & 0.014 & 0.014 \\
\hline \pm SE & 7.45 & 3.33 & 4.71 & 4.71 \\
\hline
\end{tabular}

a-c: means in the same column having different letters are significantly $(\mathrm{P} \leq 0.05)$ fifferent.

Table 2: Bacterial challenge test (Pathogenicity, \%) of O. niloticus fed the Garlen Allicin experimental diets.

\begin{tabular}{|c|c|c|c|c|}
\hline Treat & Mortality $_{\mathbf{2 4}}$ & Mortality $_{\mathbf{4 8}}$ & Mortality & Survival \\
\hline Control & $80.0^{\mathrm{a}}$ & $00.0^{\mathrm{a}}$ & $80.0^{\mathrm{a}}$ & $20.0^{\mathrm{a}}$ \\
\hline $\mathbf{G}_{\mathbf{1}}$ & $7555^{\mathrm{a}}$ & $00.0^{\mathrm{a}}$ & $73.34^{\mathrm{a}}$ & $26.66^{\mathrm{a}}$ \\
\hline $\mathbf{G}_{\mathbf{2}}$ & $82.22^{\mathrm{a}}$ & $00.0^{\mathrm{a}}$ & $86.66^{\mathrm{a}}$ & $13.34^{\mathrm{a}}$ \\
\hline $\mathbf{G}_{\mathbf{3}}$ & $82.22^{\mathrm{a}}$ & $00.0^{\mathrm{a}}$ & $86.66^{\mathrm{a}}$ & $13.34^{\mathrm{a}}$ \\
\hline $\mathbf{P}>\mathbf{F}$ & 0.330 & 00.0 & 0.363 & 0.363 \\
\hline $\mathbf{S E}$ & 2.721 & 00.0 & 1.925 & 1.925 \\
\hline
\end{tabular}

a: means in the same column having the same letter are significantly ( $\mathrm{P} \geq 0.05)$ not fifferent.

Table 3: Bacterial challenge test (Pathogenicity, \%) of O. niloticus fed the Diamond V (Original XPC) experimental diets.

\begin{tabular}{|c|c|c|c|c|}
\hline Treat & Mortality $_{\mathbf{2 4}}$ & Mortality 48 & Mortality & Survival \\
\hline Control & $80.0^{\mathrm{a}}$ & $0.0^{\mathrm{a}}$ & $80.0^{\mathrm{a}}$ & $20.0^{\mathrm{a}}$ \\
\hline $\mathbf{X P C}_{\mathbf{1}}$ & $64.33^{\mathrm{a}}$ & $17.66^{\mathrm{a}}$ & $64.33^{\mathrm{a}}$ & $35.67^{\mathrm{a}}$ \\
\hline $\mathbf{X P C}_{2}$ & $60.0^{\mathrm{a}}$ & $0.0^{\mathrm{a}}$ & $66.66^{\mathrm{a}}$ & $33.34^{\mathrm{a}}$ \\
\hline $\mathbf{X P C}_{3}$ & $77.66^{\mathrm{a}}$ & $0.0^{\mathrm{a}}$ & $80.0^{\mathrm{a}}$ & $20.0^{\mathrm{a}}$ \\
\hline $\mathbf{P}>\mathbf{F}$ & 0.001 & 0.0001 & 0.0397 & 0.00 .11 \\
\hline $\mathbf{S E}$ & 2.461 & 1.666 & 3.975 & 7.45 \\
\hline
\end{tabular}

a: means in the same column having the same letter are significantly $(\mathrm{P} \geq 0.05)$ not fifferent. 
Table 4: Comparison of bacterial challenge test (pathogenicity, \%) of O. niloticus fed the Aqua Superzyme, Garlen Allicin, and Diamond V (Original XPC) experimental diets.

\begin{tabular}{|c|c|c|c|c|}
\hline $\mathbf{T}^{*} \mathrm{~L}$ & Mortality $_{24}$ & Mortality $_{48}$ & Mortality & Survival \\
\hline Control & $80.0^{\mathrm{ab}}$ & $0.0^{\mathrm{b}}$ & $80.0^{\mathrm{a}}$ & $20.0^{\mathrm{b}}$ \\
\hline $1 * 1$ & $60.0^{\text {cd }}$ & $0.0^{\mathrm{b}}$ & $60.0^{c}$ & $40.0^{\mathrm{a}}$ \\
\hline $1 * 2$ & $53.33^{d}$ & $13.33^{\mathrm{a}}$ & $66.66^{\mathrm{bc}}$ & $33.34^{\mathrm{a}}$ \\
\hline $1 * 3$ & $86.66^{\mathrm{a}}$ & $0.0^{\mathrm{b}}$ & $86.66^{\mathrm{a}}$ & $13.34^{b}$ \\
\hline $2 * 1$ & $75.55^{\mathrm{abc}}$ & $0.0^{\mathrm{b}}$ & $77.77^{\mathrm{ab}}$ & $22.23^{b}$ \\
\hline $2 * 2$ & $82.22^{\mathrm{a}}$ & $0.0^{\mathrm{b}}$ & $82.22^{\mathrm{a}}$ & $17.78^{\mathrm{b}}$ \\
\hline $2 * 3$ & $82.22^{\mathrm{a}}$ & $0.0^{\mathrm{b}}$ & $82.22^{\mathrm{a}}$ & $17.78^{\mathrm{b}}$ \\
\hline $3 * 1$ & $64.33^{\mathrm{bcd}}$ & $17.66^{\mathrm{a}}$ & $64.33^{\mathrm{C}}$ & $35.67^{\mathrm{a}}$ \\
\hline $3 * 2$ & $60.0^{\mathrm{cd}}$ & $0.0^{\mathrm{b}}$ & $66.66^{\mathrm{bc}}$ & $33.34^{\mathrm{a}}$ \\
\hline $3 * 3$ & $77.66^{\mathrm{ab}}$ & $0.0^{b}$ & $80.0^{\mathrm{a}}$ & $20.0^{\mathrm{b}}$ \\
\hline $\mathbf{P}>\mathbf{F}$ & 0.0014 & 0.0001 & 0.0011 & 0.0001 \\
\hline$\pm \mathrm{SE}$ & 5.254 & 2.233 & 4.085 & 3.576 \\
\hline
\end{tabular}

a-c: means in the same column having different letters are significantly $(\mathrm{P} \leq 0.05)$ fifferent.

In probiotics, the bacteria produce lactic thereby lowering the $\mathrm{pH}$ that accordingly weakens the growth of most pathogenic bacteria and favour acid producers. Lactic acid bacteria are characterized as Gram positive usually nonmotile, non sporulating bacteria that produce lactic acid as a major or sole product of fermentative metabolism. Member of this group containing both rods (Lactobacillus and carnobacteia) and Cocci (Streptococci); they are generally catalase negative and they usually lack cytochromes (Sneath, 1986).

The spcies currently being used in probiotic preparation are L. bulgaricus, $L$. acidophilus, L. casi, L. helveticus, L. lactis, L. salivarvis, L. plantarum, Streptococcus thermopillus, Enterococcus faccium, Ent. falacalis, Bifidobacterium spp. and E. Coli. Consumption of Lactobacillus products and supplements cpntaining viable lactic bacteria results in their establishment in the gastrointestinal tract. Their presence in the intestinal tract has been suggested to be prophylactic, they may reduce risk associated with dietary onset of carcinogensis directly due to the prodution of procarcinogenic substances or indirectly due to the reduction in the levels of enzymes that convert procarcinogens to carcinogens. The suppression is probably medidated by lactic acid bacteria through activation of host defense system (Fernandes and Shahani, 1990).

Perdigon et al. (1990) indicated that feeding with Lactobacillus casei and Streptococcus salivsius spp. protect against Salmonells tyhimurium, the protective effect of $L$. casei against $S$. typhimurium was associated mainly to 1 gA production in intestinal secretions. However, Probiotics (specific microbial feeds with potential benefits to the host), and prebiotics (dietary components such as complex carbohydrates able to change the colonic microenvironment fostering colonization with non-enteropathogens) are areas of current interest because they offer alternatives for the management of the growing problem of multiple antibiotic resistance and overwhelming infections in the hospitalized patient (Josephlevy, 1998).

The research of probiotics for aquatic animals is increasing with the demand for environment friendly aquaculture. The probiotics were defined as live microbial feed supplements that biocontrol and antagonist pathogens. Many other beneficial effects may be expected from probiotics, e.g., stimulation of the immune system. The most promising prospects are sketched out, but considerable efforts of research will be necessary to develop the applications to aquaculture (Gatesoupe, 1999 and Castillo, 2008). 
In other investigation, Verschuere et al. (2000) reviewed the probiotic bacteria as biological control agents in aquaculture. They cited that in aquaculture system, the immediate ambient environment has a much larger influences on the health status than with terrestrial animals or humans; since in the aquatic environment, hosts and microorganisms share the ecosystem. Much more than terrestrial animals, aquatic farmed animals are surrounded by an environment that supports their pathogens independently of the host animals, and so (opportunistic) pathogens can reach high densities around the animal. Surrounding bacteria are continuously ingested either with the feed or when the host is drinking. They concluded that probiotics enhance the immune response. So, Poole et al. (2007) recorded that the emergence of multidrug resistant pathogens has stimulated a need to find alternatives to antimicrobials. Thus, Abdelhamid et al. (2008) used the Trichoderma viride for biological control of fungal (Saprolegnia sp. and Aspergillus ochraceus) diseases of fish.

Abd El-Rahman and El-Bana (2006) used Micrococcus luteus as a bacterial probiotic which presented in vitro and in vivo antagonistic effects against the pathogenic bacteria Aeromonas hydrophila. Also, Taoka et al. (2006) indicated that probiotics treatment is promising as an alternative method to antibiotics for disease prevention in aquaculture. However, dietary supplementation of probiotic and vitamin C improved the immune response of fish (Nayak et al., 2007 and Panigrahi et al., 2007) as well as fish health (Panigrahi and Azad, 2007). Moreover, Abdel-Tawwab et al. (2008); Aly et al. (2008c); El-Ashram et al. (2008); Marzouk et al. (2008); Wang et al. (2008 a and b); Abd El-Aziz et al. (2009) and El-Nobi et al. (2009) studied the effect of probiotics on survival and resistance of fish.

Moreover, Aly et al. (2008a) found that some Bacillus and Citrobacter strains isolated from Nile tilapia (B. pumilus, B. firmus, and $C$. freundii) showed inhibitory effects against $A$. hydrophila. To evaluate the use of commercial live bakers' yeast, Saccharomyces cerevisiae as an immunity promoter for Nile tilapia, Oreochromis niloticus (L.), fish (0.33 g) were fed a diet containing 0.0, 0.25, 0.50, 1.0, 2.0, or $5.0 \mathrm{~g}$ yeast/kg diet for 12 weeks. After the 12-week experimental period, fish of each treatment were challenged by pathogenic Aeromonas hydrophila, which was given by interperitoneal (IP) injection and kept under observation for 10 days to record clinical signs and the daily mortality rate. Total fish mortality 10-days after IP injection with A. hydrophila and its count after incubation with fish serum decreased with the increase of yeast level in fish diets. However, the lowest fish mortality and bacterial counts were obtained in fish fed $5.0 \mathrm{~g}$ yeast $/ \mathrm{kg}$. These results indicate that bakers' yeast supplement is promising as an alternative method to antibiotics for disease prevention in tilapia aquaculture, and the optimum level of live bakers' yeast is about 1.0 g per kg diet (Abdel-Tawwab et al., 2008).

Also, Aly et al. (2008b) reported that the probiotic activity of two bacteria (Bacillus subtilis and Lactobacillus acidophilus) was evaluated by its effect on the immune response of Nile tilapia (Oreochromis niloticus), beside its protective effect against challenge infection. The in-vitro antimicrobial assay showed that Bacillus subtilis and Lactobacillus acidophilus inhibited the growth of A. hydrophila. The $B$. subtilis inhibited the development of $P$. fluorescens while $L$. acidophilus inhibited the growth of Strept. iniae. The B. subtilis and L. acidophilus proved harmless when injected in the $O$. niloticus. The serum bactericidal activity was high in the group that was given a mixture of the two bacteria. However, during the past two decades, the use of probiotics as an alternative to the use of antibiotics has shown to be promising in aquaculture, particularly in fish and shellfish larviculture (Tinh et al., 2008). 
Moreover, Abdelhamid et al. (2009) showed the positive effect of the prebiotic "T-Protphyt 2000" at the two concentrations against all the tested bathogenic bacteria and showed nearly no clear difference between the two concentrations of prebiotic. Also, it has a similar effect of that of the antibiotic (OTC), especially with the pathogenic bacteria, Aeromonas and Pseudomonas, which showed sensitivity towards prebiotic, while the Vibrio sp. showed resistance to OTC at the two concentrations. The prebiotics T-Protphyt 2000 and Bio-Mos ${ }^{\circledR}$ (Abdelhamid et al., 2009 and 2012) improved also fish performance as a consecoence of the positive effects of the prebiotics on fish health and resistance.

Probiotic bacteria Micrococcus species isolated from the gonads of apparently healthy Oreochromis niloticus had antagonistic effect against the pathogenic Aeromonas hydrophila in vitro. The inhibition zone to A. hydrohpila was $47 \mathrm{~mm}$ in diameter due to M. species (Osman et al., 2010). Algedawy et al. (2011) concluded that the probiotic Biogen ${ }^{\circledR}$ is superior to the multienzyme mixture Natuzyme ${ }^{\circledR}$ for improving the cellular and humoral immune responses. Moreover, Dietary supplementation of $B$. subtilis at a dose of $1.35 \times 10^{7} \mathrm{cfu} \mathrm{g}^{-1}$ improved non-specific immune responses and disease resistance of juvenile large yellow croaker, $L$. crocea (Ai et al., 2011).

Some pre-and pro-biotics as powders (mainly T-Protphyt 2000, Bio-Mos ${ }^{\circledR}$, European Instand Dry Baker's Yeast, P ROBAX, and Bio BUDS) were tested in laboratory for their efficacy as bactericides. The bactericidal activity of these pre-and pro-biotics was tested in vitro against nine of pathogenic strains of Gram -negative and positive bacteria (Aeromonas hydrophilla, Pseudomonas aeruginosa, Pseudomonas fluorescence, Vibrio spp., Klebsiella spp., Shigella spp., Salmonella spp., Proteus spp., and Escherichia coli) at two concentrations compared with oxytetracycline. The results showed positive effect of these pre-and pro-biotics at the two concentrations against all the tested bacteria (Abdelhamid and El-Barbar, 2013).

Gut microbiology and indigenous gut histology of Atlantic salmon (Salmo salar L.) was investigated following feeding of a control and a prebiotic (EWOS prebiosal $^{\circledR}$ ) diet and ex vivo exposure to saline or the probiotic bacterium Carnobacterium divergens. The results showed that ex vivo exposure of $C$. divergens at $10^{8} \mathrm{CFU} \mathrm{ml}{ }^{-1}$ did not cause cell damage to the intestine tract of Atlantic salmon. Furthermore, prior provision of dietary prebiotic elevated the ability of $C$. divergens to adhere to the epithelium or mucus layer in the proximal intestine, where culturable heterotrophic bacterial levels (which were identified as $C$. divergens) were elevated by $234 \%$ compared to the control. This effect was not apparent in the distal intestine. The ability of isolated carnobacteria from the ex vivo experiment to inhibit growth of two fish pathogenic bacteria (Yersinia rückeri and Aeromonas salmonicida ssp. salmonicida) was assessed. Extracellular products from all 11 of the isolated carnobacteria strains, plus the type strain Carnobacterium inhibens CCUG 31728, inhibited the in vitro growth of $Y$. rückeri. However, only extracellular products from C. divergens isolate 57 inhibited the growth of A. salmonicida ssp. Salmonicida (Kristiansen et al., 2013).

\section{Haematology:}

The haematological parameters' values increased significantly $(\mathrm{P} \leq 0.05)$ by using Aqua Superzyme, particularly $A_{1}$ (Table 5); Garlen Allicin, particularly $G_{1}$ (Table 6); and Diamond V (Original XPC), particularly $\mathrm{XPC}_{1}$ (Table 7). Yet, the overall significantly $(\mathrm{P} \leq 0.05)$ best valus for all tested parameters among additives and their levels was $1 * 2$, i.e. Aqua Superzyme at $0.02 \%$ of the diet (Table 8 ). 
The research of probiotics for aquatic animals is increasing with the demand for environmentfriendly aquaculture. The extension of the probiotic concept is pertinent when the administered microbes survive in the gastrointestinal tract. Otherwise, more general terms are suggested, like biocontrol when the treatment is antagonistic to pathogens, or bioremediation when water quality is improved. Three main characteristics have been searched in microbes as candidates to improve the health of their host. 1. The antagonism to pathogens was shown in vitro in most cases. 2 . The colonization potential of some candidate probionts was also studied. 3. Challenge tests confirmed that some strains could increase the resistance to disease of their host. Many other beneficial effects may be expected from probiotics, e.g., competition with pathogens for nutrients or for adhesion sites, and stimulation of the immune system. The most promising prospects are sketched out, but considerable efforts of research will be necessary to develop the applications to aquaculture (Gatesoupe, 1999).

Table 5: Mean immunity index values for Nile tilapia (O. niloticus) fed the Aqua Superzyme containing experimental diets.

\begin{tabular}{|c|c|c|c|c|c|c|c|c|}
\hline Treat. & Hb, g/dl & $\begin{array}{c}\text { RBCs } \times \\
106 / \mathrm{mm} 3\end{array}$ & НСТ,\% & $\begin{array}{c}P . \\
\times 10^{3} / \mathrm{mm}^{3} \\
\end{array}$ & $\begin{array}{c}\text { WBCs } \\
\times 10^{3} / \mathbf{m m}^{3} \\
\end{array}$ & $\begin{array}{c}\mathrm{N} . \\
\times 10^{3} / \mathrm{mm}^{3} \\
\end{array}$ & $\begin{array}{c}\text { L. } \\
\times 10^{3} / \mathrm{mm}^{3} \\
\end{array}$ & $\begin{array}{c}\text { M. } \\
\times 10^{3} / \mathbf{m m}^{3} \\
\end{array}$ \\
\hline Control & $4.60 \mathrm{~b}$ & $1.70 \mathrm{c}$ & $13.20 \mathrm{c}$ & $25.0 \mathrm{c}$ & $19.06 \mathrm{c}$ & $7.10 \mathrm{c}$ & 11.50b & $1.0 \mathrm{~b}$ \\
\hline A1 & $6.53 \mathrm{a}$ & $2.20 \mathrm{ab}$ & $20.76 \mathrm{ab}$ & $37.0 \mathrm{a}$ & $24.30 \mathrm{a}$ & $9.16 \mathrm{a}$ & $13.56 \mathrm{a}$ & $1.20 \mathrm{a}$ \\
\hline A2 & $6.70 \mathrm{a}$ & $2.23 \mathrm{a}$ & $21.23 \mathrm{a}$ & $34.66 \mathrm{ab}$ & $22.66 \mathrm{~b}$ & $8.46 \mathrm{~b}$ & 12.63ab & 1.10ab \\
\hline A3 & $6.0 \mathrm{a}$ & $1.90 \mathrm{bc}$ & $18.56 \mathrm{~b}$ & $32.66 \mathrm{~b}$ & $22.30 \mathrm{~b}$ & $8.20 \mathrm{~b}$ & 12.43ab & $1.03 \mathrm{~b}$ \\
\hline $\mathbf{P}>\mathbf{F}$ & 0.005 & 0.010 & 0.0002 & 0.0001 & 0.0001 & 0.0004 & 0.016 & 0.052 \\
\hline$\pm \mathrm{SE}$ & 0.314 & 0.092 & 0.754 & 0.942 & 0.412 & 0.186 & 0.336 & 0.044 \\
\hline
\end{tabular}

a-c: means in the same column having different letters are significantly $(\mathrm{P} \leq 0.05)$ fifferent.

Hb: haemoglobin, $\mathrm{RBC}_{\mathrm{s}}$ : red blood cells, HCT: haematocrit, P: Platelets, $\mathrm{WBC}_{\mathrm{s}}$ : white blood cells, N:

Neutrophil, L: Lymphocyte, M: Monocyte.

Table 6: Mean immunity index values for Nile tilapia (O. niloticus) fed the Garlen Allicin containing experimental diets.

\begin{tabular}{|c|c|c|c|c|c|c|c|c|}
\hline Treat. & $\mathrm{Hb}, \mathrm{g} / \mathrm{dl}$ & $\begin{array}{c}\text { RBCs } \times \\
10^{6} / \mathrm{mm}^{3}\end{array}$ & HCT, \% & $\begin{array}{c}P . \\
\times 10^{3} / \mathrm{mm}^{3}\end{array}$ & $\begin{array}{c}\text { WBCs } \\
\times 10^{3} / \mathrm{mm}^{3}\end{array}$ & $\begin{array}{c}\mathrm{N} . \\
\times 10^{3} / \mathrm{mm}^{3}\end{array}$ & $\begin{array}{c}\text { L. } \\
\times 10^{3} / \mathrm{mm}^{3}\end{array}$ & $\begin{array}{c}\text { M. } \\
\times 10^{3} / \mathrm{mm}^{3} \\
\end{array}$ \\
\hline Control & $4.60 \mathrm{~b}$ & $1.70 \mathrm{~b}$ & $13.20 \mathrm{c}$ & $25.0 \mathrm{~b}$ & $19.06 \mathrm{c}$ & $7.10 \mathrm{~b}$ & $11.50 \mathrm{a}$ & $1.0 \mathrm{a}$ \\
\hline $\mathrm{G}_{1}$ & $6.20 \mathrm{a}$ & $2.03 \mathrm{a}$ & $19.66 \mathrm{a}$ & $29.0 \mathrm{a}$ & $21.93 \mathrm{a}$ & $8.06 a$ & $12.06 \mathrm{a}$ & $1.03 \mathrm{a}$ \\
\hline $\mathbf{G}_{2}$ & $5.16 \mathrm{~b}$ & $1.80 \mathrm{~b}$ & $16.20 \mathrm{~b}$ & $27.0 \mathrm{ab}$ & $21.06 \mathrm{ab}$ & 7.96a & $11.80 \mathrm{a}$ & $1.03 a$ \\
\hline $\mathbf{G}_{3}$ & $5.23 \mathrm{~b}$ & $1.80 \mathrm{~b}$ & $16.36 b$ & $28.66 a$ & $20.43 b c$ & $8.03 a$ & $11.36 \mathrm{a}$ & $1.03 a$ \\
\hline $\mathbf{P}>\mathbf{F}$ & 0.015 & 0.039 & 0.002 & 0.010 & 0.009 & 0.001 & 0.35 & 0.915 \\
\hline$\pm \mathrm{SE}$ & 0.26 & 0.06 & 0.76 & 0.66 & 0.43 & 0.12 & 0.28 & 0.04 \\
\hline
\end{tabular}

a-c: means in the same column having different letters are significantly $(\mathrm{P} \leq 0.05)$ fifferent.

Hb: haemoglobin, $\mathrm{RBC}_{\mathrm{s}}$ : red blood cells, HCT: haematocrit, P: Platelets, $\mathrm{WBC}_{\mathrm{s}}$ : white blood cells, N:

Neutrophil, L: Lymphocyte, M: Monocyte.

Table 7: Mean immunity index values for Nile tilapia (O. niloticus) fed the Diamond V (Original XPC) containing experimental diets.

\begin{tabular}{|c|c|c|c|c|c|c|c|c|}
\hline Treat. & $\begin{array}{l}\text { Hb, } \\
\text { g/dl }\end{array}$ & $\begin{array}{c}\text { RBCs } \times \\
10^{6} / \mathrm{mm}^{3}\end{array}$ & НСТ,\% & $\begin{array}{c}P . \\
\times 10^{3} / \mathrm{mm}^{3}\end{array}$ & $\begin{array}{c}\text { WBCs } \\
\times 10^{3} / \mathbf{m m}^{3}\end{array}$ & $\begin{array}{c}\mathrm{N} . \\
\times 10^{3} / \mathrm{mm}^{3}\end{array}$ & $\begin{array}{c}\text { L. } \\
\times 10^{3} / \mathrm{mm}^{3}\end{array}$ & $\underset{\times 10^{3} / \mathrm{mm}^{3}}{\text { M. }}$ \\
\hline Control & $4.60^{\mathrm{a}}$ & $1.70^{\mathrm{a}}$ & $13.20^{b}$ & $25.0^{\mathrm{a}}$ & $19.06^{b}$ & $7.10^{b}$ & $11.50^{\mathrm{a}}$ & $1.0^{\mathrm{a}}$ \\
\hline $\mathrm{XPC}_{1}$ & $5.76^{\mathrm{a}}$ & $1.83^{\mathrm{a}}$ & $16.20^{\mathrm{a}}$ & $26.66^{\mathrm{a}}$ & $20.03^{\mathrm{ab}}$ & $7.83^{\mathrm{a}}$ & $11.57^{\mathrm{a}}$ & $1.03^{\mathrm{a}}$ \\
\hline $\mathrm{XPC}_{2}$ & $4.73^{a}$ & $1.73^{\mathrm{a}}$ & $14.16^{\mathrm{ab}}$ & $24.83^{\mathrm{a}}$ & $21.26^{\mathrm{a}}$ & $7.23^{\mathrm{ab}}$ & $12.30^{\mathrm{a}}$ & $1.03^{\mathrm{a}}$ \\
\hline $\mathrm{XPC}_{3}$ & $4.73^{\mathrm{a}}$ & $1.70^{\mathrm{a}}$ & $14.16^{\mathrm{ab}}$ & $26.0^{\mathrm{a}}$ & $20.53^{\mathrm{a}}$ & $7.46^{\mathrm{ab}}$ & $12.03^{\mathrm{a}}$ & $1.03^{\mathrm{a}}$ \\
\hline $\mathbf{P}>\mathbf{F}$ & 0.015 & 0.50 & 0.090 & 0.12 & 0.037 & 0.126 & 0.20 & 0.91 \\
\hline$\pm \mathrm{SE}$ & 0.35 & 0.068 & 0.72 & 0.53 & 0.43 & 0.20 & 0.27 & 0.041 \\
\hline
\end{tabular}

a-b: means in the same column having different letters are significantly $(\mathrm{P} \leq 0.05)$ fifferent.

Hb: haemoglobin, $\mathrm{RBC}_{\mathrm{s}}$ : red blood cells, HCT: haematocrit, P: Platelets, $\mathrm{WBC}_{\mathrm{s}}$ : white blood cells, N:

Neutrophil, L: Lymphocyte, M: Monocyte. 
Table 8: Comparison among mean immunity index values for Nile tilapia (O.niloticus) fed the Aqua Superzyme, Garlen Allicin, and Diamond V (Original XPC) containing experimental diets.

\begin{tabular}{|c|c|c|c|c|c|c|c|c|}
\hline Treat. & Hb, g/dl & $\begin{array}{c}\text { RBCs } \times \\
10^{6} / \mathbf{m m}^{3}\end{array}$ & HCT, \% & $\begin{array}{c}P . \\
\times 10^{3} / \mathrm{mm}^{3}\end{array}$ & $\begin{array}{c}\text { WBCs } \\
\times 10^{3} / \mathrm{mm}^{3}\end{array}$ & $\begin{array}{c}\mathrm{N} . \\
\times 10^{3} / \mathrm{mm}^{3}\end{array}$ & $\begin{array}{c}\text { L. } \\
\times 10^{3} / \mathrm{mm}^{3}\end{array}$ & $\begin{array}{c}\text { M. } \\
\times 10^{3} / \mathrm{mm}^{3}\end{array}$ \\
\hline Control & $4.60^{\mathrm{d}}$ & $1.70^{c}$ & $13.20 \mathrm{e}$ & $25.0^{\mathrm{d}}$ & $19.06^{\mathrm{g}}$ & $7.10^{\mathrm{e}}$ & $11.50^{\mathrm{de}}$ & $1.0^{\mathrm{b}}$ \\
\hline $1 * 1$ & $6.53^{\mathrm{a}}$ & $2.20^{\mathrm{a}}$ & $20.76^{\mathrm{ab}}$ & $37.0^{\mathrm{a}}$ & $24.30^{\mathrm{a}}$ & $9.16^{\mathrm{a}}$ & $13.56^{\mathrm{a}}$ & $1.20^{\mathrm{a}}$ \\
\hline $1 * 2$ & $6.70^{\mathrm{a}}$ & $2.23^{\mathrm{a}}$ & $21.23^{\mathrm{a}}$ & $34.66^{\mathrm{ab}}$ & $22.66^{\mathrm{b}}$ & $8.46^{\mathrm{b}}$ & $12.63^{b}$ & $1.10^{\mathrm{ab}}$ \\
\hline $1 * 3$ & $6.0^{\mathrm{ab}}$ & $1.90^{\mathrm{bc}}$ & $18.56^{\mathrm{bc}}$ & $32.66^{\mathrm{b}}$ & $22.30^{\mathrm{bc}}$ & $8.20^{\mathrm{bc}}$ & $12.43^{\mathrm{bc}}$ & $1.033^{\mathrm{b}}$ \\
\hline $2 * 1$ & $6.20^{\mathrm{ab}}$ & $2.03^{\mathrm{ab}}$ & $19.66^{\mathrm{ab}}$ & $29.0^{C}$ & $21.93^{\text {bcd }}$ & $8.06^{\mathrm{bcd}}$ & $12.06^{\text {bcde }}$ & $1.033^{b}$ \\
\hline $2 * 2$ & $5.16^{\mathrm{bcd}}$ & $1.80^{\mathrm{bc}}$ & $16.20^{\mathrm{cd}}$ & $27.0^{\mathrm{cd}}$ & $21.06^{\text {def }}$ & $7.96^{\mathrm{bcd}}$ & $11.80^{\text {bcde }}$ & $1.033^{b}$ \\
\hline $2 * 3$ & $5.23^{\mathrm{bcd}}$ & $1.80^{\mathrm{bc}}$ & $16.36^{\mathrm{cd}}$ & $28.66^{c}$ & $20.43^{\mathrm{ef}}$ & $8.03^{\mathrm{bcd}}$ & $11.36^{\mathrm{e}}$ & $1.033^{b}$ \\
\hline $3 * 1$ & $5.76^{\mathrm{abc}}$ & $1.83^{\mathrm{bc}}$ & $16.20^{\text {cd }}$ & $26.66^{\mathrm{cd}}$ & $20.03^{\mathrm{fg}}$ & $7.83^{\mathrm{cd}}$ & $11.56^{\text {cde }}$ & $1.033^{b}$ \\
\hline $3 * 2$ & $4.73^{\mathrm{cd}}$ & $1.73^{\mathrm{C}}$ & $14.16^{\mathrm{de}}$ & $24.83^{\mathrm{d}}$ & $21.26^{\text {cde }}$ & $7.23^{\mathrm{e}}$ & $12.30^{\mathrm{bcd}}$ & $1.033^{b}$ \\
\hline $3 * 3$ & $4.73^{\mathrm{cd}}$ & $1.70^{\mathrm{C}}$ & $14.16^{\mathrm{de}}$ & $26.0^{\mathrm{d}}$ & $20.53^{\mathrm{ef}}$ & $7.46^{\mathrm{de}}$ & $12.03^{\text {bcde }}$ & $1.033^{b}$ \\
\hline $\mathbf{P}>\mathbf{F}$ & 0.0005 & 0.0004 & 0.0001 & 0.0001 & 0.0001 & 0.0001 & 0.0005 & 0.0622 \\
\hline$\pm \mathrm{SE}$ & 0.320 & 0.080 & 0.743 & 0.804 & 0.368 & 0.188 & 0.271 & 0.0380 \\
\hline
\end{tabular}

a-g: means in the same column having different letters are significantly $(\mathrm{P} \leq 0.05)$ fifferent.

Hb: haemoglobin, $\mathrm{RBC}_{\mathrm{s}}$ : red blood cells, HCT: haematocrit, P: Platelets, $\mathrm{WBC}_{\mathrm{s}}$ : white blood cells, N:

Neutrophil, L: Lymphocyte, M: Monocyte.

Kobeisy and Hussein (1995) found that dietary live yeast may improve the haematological picture in Nile tilapia. Also, Irianto and Austin (2002) cited that probiotics actively inhibit the colonization of potential pathogens in the digestive tract by antibiosis or by competetion for ntrients and/or space, alteration of microbial metabolism, and/or by the stimulation of host immunity. Probiotics may stimulate appetite and improve nutrition by the production of vitamins, detoxification of indigestible components. Moreover, Sahan and Duman (2008) found that haematocrit, leucocytes, monocytes, and neutrophils were increased in common carp fed with beta glucan. Also, Aly et al. (2008c) showed significant increase in haematocrit values in group of Nile tilapia fed the mixture of $B$. subtilis and $L$. acidophilus comparing with the control.

Aquaculture is one of the fastest developing growth sectors in the world. However, disease outbreaks are constraint to aquaculture production, thereby affects both economic development of the country and socio-economic status of the local people in many countries. Disease control in aquaculture industry has been achieved by following different methods using traditional ways, synthetic chemicals and antibiotics. However, the use of such expensive chemotherapeutants for controlling diseases has been widely criticized for their negative impacts like accumulation of residues, development of drug resistance, immunosuppressants and reduced consumer preference for aqua products treated with antibiotics and traditional methods are ineffective against controlling new diseases in large aquaculture systems. Therefore, alternative methods need to be developed to maintain a healthy microbial environment in the aquaculture systems there by to maintain the health of the cultured organisms. Use of probiotics is one of such method that is gaining importance in controlling potential pathogens. This review provides a summary of the criteria for the selection of the potential probiotics, their importance and future perspectives in aquaculture industry (Sahu et al., 2008).

Amer (2012) concluded that Diamond V XP (inactive yeast a commercial product containing 100\% dried Saccharomyces cerevisae distributed by DIAMOND V mils, Cidar Rapids, IOWA, and USA) could be used successfully as feed additive for feeding Nile tilapia Oreochromis niloticus without any adverse effects on their productive performance. It could be suggested that dietary supplement with Diamond $\mathrm{V} \mathrm{XP} \mathrm{(1.5g)} \mathrm{is} \mathrm{useful} \mathrm{in} \mathrm{the} \mathrm{intensive} \mathrm{production} \mathrm{system} \mathrm{of} \mathrm{fish.}$ 
Hassan (2013) obtained results concerning the effects of the probiotic Hydroyeast Aquaculture $^{\circledR}$ on adult male O. niloticus showed that the $15 \mathrm{~g} / \mathrm{kg}$ diet realized best significantly $(\mathrm{P} \leq 0.05)$ values for RBCs count, $\mathrm{PCV} \%$, and WBCs count, followed by $10 \mathrm{~g}$ probiotic/kg diet compared with the control group. However, about adult females' $O$. niloticus, the $10 \mathrm{~g}$ probiotic/kg diet was the best treatment concerning the significantly ( $\mathrm{R} 0.05)$ improvement of the hematological parame ters (Hb content, RBCs count, PCV\% and WBCs count). So, based on the obtained results, the optimum level of the tested probiotic Hydroyeast Aquaculture ${ }^{\circledR}$ was depinding on fish sex.

\section{REFERENCES}

Abd El-Aziz, M.; Ali, M. Yassin, S. Raafat, A. Moustafa, M. and Rashad, S. (2009). Effect of some probiotics on Oreochromis niloticus experimentally infected by Aeromonas hydrophila. Global Fish. \& Aquacult. Rese. Conference, Cairo, p: 24.

Abdelhamid, A.M. and El-Barbary, M.I. (2013). An in vitro study on the effect of some pre and probiotics on some pathogenic bacteria. Engormix.com, Aquaculture Technical articles, Nutrition, 20p.

Abdelhamid, A. M.; El-Barbary, M.I. and Hasan, M. M. M. (2012). Effect of dietary supplementation with Bio-mos ${ }^{\circledR}$ or T-protphyt 2000 with and without hormone treatment on performance, chemical composition, and hormone residues of mono-sex Nile tilapia. J. Anim. \& Poul. Prod. Mansoura Univ., 3: 99-113.

Abdelhamid, A. M.; Mehrim, A. I.; El-Barbary, M. I.; Ibrahim, S. M. and AbdelWahab, A. I. (2009). Evaluation of a new Egyptian probiotic by African catfish fingerlings. J. Environ. Sci. \& Technol., 2(2):133-145 (engormix.com, Aquaculture Technical Articles, 13 p).

Abdelhamid, A.M.; Seden, M.A.L. and Zenhom, O. A. (2013). Effect of different sources and levels of some dietary biological additives on: I- growth performance and production economy of Nile tilapia fish. J. Anim. \& Poul. Prod. Mansoura Univ., 4 (11): 615-634.

Abd El-Rahman, A.M.M. and El-Bana, L.F.A. (2006). Using of Micrococcus luteus as a probiotic bacteria among cultured Oreochromis niloticus, SCVMJ, X, (1): $73-82$.

Abdel-Tawwab, M.; Abdel-Rahman, A.M. and Ismael, N.E.M. (2008). Evaluation of commercial live bakers' yeast, Saccharomyces cerevisiae as a growth and immunity promoter for fry Nile tilapia, Oreochromis niloticus (L.) challenged in situ with Aeromonas hydrophila. Aquacult., 280: 185-189.

Ai, Q.; Xu, H., Mai, K., Xu, W., Wang, J. and Zhang, W. (2011). Effects of dietary supplementation of Bacillus subtilis and fructooligosaccharide on growth performance, survival, non-specific immune response and disease resistance of juvenile large yellow croaker, Larimichthys crocea. Aquaculture, 317: 155-161.

Algedawy, S. A., Soliman, K. K., Elashmawy, I.M. And El-Sayed, Y. S. (2011). Effect of commercial probiotic and exogenous enzymes on the growth performance, immune response, and hemato-biochemical parameters of broiler chickens. The $4^{\text {th }}$ Sci. Conf. of Animal Wealth Research in the Middle East \& North Africa, p: 23 (Abstract).

Aly, S. M.; Abdel Atti, N. M. and Mohamed, M. F. (2008a). Effect of garlic on the survival, growth, resistance and quality of Oreochromis niloticus. $8^{\text {th }}$ Inter. Symp. on Tilapia in Aquacul.,Cairo, pp: 277-296. 
Aly, S.M., Abd-El-Rahman, A.M. John, G. and Mohamed, M.F. (2008b). Characterization of some bacteria isolated from Oreochromis niloticus and their potential use as probiotics. Aquacult., 277: $1-6$.

Aly, S.M., Ahmed, Y.A. Ghareeb, A.A. and Mohamed, M.F. (2008c). Studies on Bacillus subtilis and Lactobacillus acidophilus, as potential probiotics, on the immune response and resistance of tilapia nilotica (Oreochromis niloticus) to challenge infections. Fish and Shellfish Immunology, 25: 128 - 136.

Amer, A.A.A.M. (2012). Effect of different levels of protein and probiotics on productive performance of fresh water fishes. M.Sc., Fac. Agric., Kafrelsheikh Univ.

Castillo, M. (2008). Blocking pathogens with Bacillus strains. Feed-Mix, 16 (5): 19.

Duncan, D. (1955). Multiple range and multiple F-tests. Biometrics, 11: 1-42.

El-Ashram, A.M.M., Mohammed, M.F. and Aly, S.M. (2008). Effect of Biobuds ${ }^{\circledR}$ as a commercial probiotic product in cultured tilapia. $8^{\text {th }}$ International Symposium on Tilapia in Aquaculture, Oct., Cairo, Egypt, pp: 1089 - 1096.

El-Nobi, G. A.; Reda, R. M. Hassanin, M. E. and Elmowalid, G. (2009). The impact of applications of probiotic Bacillus subtilis on health and growth of koi carp Cyprinus carpio. Global Fisheries \& Aquaculture Research Conference, Cairo, p: 38.

Fernandes, C.F. and Shahani. K.M. (1990). Aiiiicarcinogcnic and inimunological properties of dietary Lactobacilli. J. Food protect, 53: 704-710.

Gatesoupe, F.J. (1999). The use of probiotics in aquaculture. Aquacult., 180:147-165.

Gibson, G.R. and Fuller, R. (2000). Aspects of iu vitro and in vivo research approaches directed towards identifying probiotics and preluolics lor human me.J. Nutr, 130:391-395.

Hassan, M.E.M. (2013). Physiological Studies on Fish Production. M.Sc. Thesis, Fac. Agric., Al-Mansoura Univ.

Irianto, A. and Austin, B. (2002). Review, Probiotics in aquaculture. Journal of Fish Diseases, 25: $633-642$.

Josephlevy, M. D. (1998). Immunonutrition: The Pediatric Experience. Nutrition, 14 (7/8): 641-647.

Kobeisy, M.A. and Hussein, S.Y. (1995). Influence of dietary live yeast on growth performance and some blood constituents in Oreochromis niloticus Proc. $5^{\text {th }}$ Sci. Conf. Animal Nutrition, 12-12 Dec., P 417-425, Ismailia, Dec.

Kristiansen, M.; Ringø, E., Merrifield, D., Vecino, J.G. and Myklebust, R. (2013). Evaluation of Prebiotic and Probiotic Effects on the Intestinal Gut Microbiota and Histology of Atlantic salmon (Salmo salar L.). Engormix.com, Aquaculture Technical articles, Nutrition, 14.

Kumar, U.S.; Vijaysarnthi, S.K. and Kaq, S. (2003). Effect ol feeding probiotics on He performance of broiiejs in. cxpcrimculal fowl typhoid. Indian vet.80: 52-55.

Marzouk, M.S., Moustafa, M.M. and Mohamed, N.M. (2008). The influence of some probiotics on the growth performance and intestinal microbial flora of Oreochromis niloticus. Proceedings of $8^{\text {th }}$ International Symposium on Tilapia in Aquaculture, Cairo, Egypt, pp. 1059-1071.

Natt, M.P. and Herrick, C.A. (1952). A new blood diluent for counting erythrocytes and leucocytes of the chicken. Poul. Sci., 31:735-738.

Nayak, S. K.; Swain, P. and Mukherjee, S. C. (2007). Effect of dietary supplementation of probiotic and vitamin $\mathrm{C}$ on the immune response of Indian major carp, Labeo rohita (Ham.). Fish \& Shellfish Immunology, 23: 892-896. 
Osman, H. A. M.; Ibrahim, T. B., Soliman, W. and Aboud, O. (2010). Improvement growth and immune status using a potential probiotic bacteria Micrococcus species among cultured Oreochromis niloticus. New York Sci. J., 3(10): 5-11.

Pangrahi, A. and Azad, I. S. (2007). Microbial intervention for better fish health in aquaculture: the Indian scenario. Fish Physiol. Biochem., 33: 429-440.

Pangrahi, A.; Kiron, V. Satoh, S. Hirono, I.Kobayashi, T. Sugita, H. Puangkaew, J. and Aoki, T. (2007). Immune modulation and expression of cytokine genes in rainbow trout Oncorhynchus mykiss upon probiotic feeding. Development and Comparative Immunology, 31: 372-382.

Patterson, J A. and Burkholder, K.M. (2003). Application of probiotics and probiotics in poultry production. Poult. Sri., 82: 627-631

Perdigon, G.; Alvarez, S.; Nader Be Marias, M. It..; Roux. M.S and Holgado, A.P. (1990): The oral administration of Lactic acid bacteria increase Ihc mucosal intestinal immunity iu response to Enleropalhogens. I. food Protect., 53: 404-410.

Poole, T., Callaway, T. and Nisbet, D. (2007). Alternatives to Antimicrobials. Infectious Disease: Foodborne Diseases. Edited by: S. Simjee ${ }^{\odot}$ Humana Press Inc.,Totowa, NJ (p: 419).

Sahan, A. and Duman, S. (2008). Effects of diet with $\beta-1,3 / 1,6$ glucan on some haematological parameters in common carp (Cyprinus carpio L., 1758) infected by ecto-parasites. Proc. Of Middle East \& North Africa Conf. for Future of Animal Wealth, Cairo, Egypt, 16-18 Oct.

Sahu, M.K.; Swarnakumar, N.S., Sivakumar, K., Thangaradjou, T. and Kannan, L. (2008). Probiotics in aquaculture: importance and future perspectives. Indian J. Microbiol., $10 \mathrm{p}$.

SAS (2006). SAS statistical guide for personal computer, SAS Institute Inc. Cary, NC.

Schalm O. W. (1975). Veterinary Haematology $3^{\text {rd }}$ Ed, Bailliere, Tindall and Cassel Ltd., London.

Schaperclaus, W.; Kulow, H.and Schreckenbach, K. (1992). Fish diseases volume 1$5^{\text {th }}$ edition.

Sneath, P.H.A. (1986). Endo spore- forming gram- positive rods and cocci. P, 11041207.In: J .G. Holt (ed.), Bergey's manual of systematic bacteriology vol.2. Williams and Wikins, Baltimore, Md.

Stoskopf, M.K. (1993). Fish Medicine. W.B. Saunders Company Harcour Brace Lovanovish, Inc.

Taoka, Y., Maeda, H., Jo, J.Y., Jeon, M.J., Bai, S.C., Lee, W.J., Yuge, K. and Koshio, S. (2006). Growth, stress tolerance and non-specific immune response of Japanese flounder Paralichthys olivaceus to probiotics in a closed recirculating system. Fish Sci., 72: 310-321.

Tinh, N.T.N., Direckens, K., Sorgeloos, P. and Bossier, P. (2008). A review of the functionality of probiotics in the larviculture food chain. Mar. Biotechnol., 10: $1-12$.

Verschuere, L., Rombaut, G., Sorgeloos, P. and Verstraete, W. (2000). Probiotic bacteria as biological control agents in aquaculture. Microbiology and Molecular Biology review, 64 (4): 655-671.

Wang, Y.B., Li, J. and Lin, J. (2008a). Probiotics in aquaculture: Challenges and outlook. Aquacult., 281: 1-4. 
Wang, Y.B., Tian, Z., Yao, J. and Li, W. (2008b). Effect of probiotics, Enteroccus faecium, on tilapia (Oreochromis niloticus) growth performance and immune response. Aquacult., 277: 203-207.

Wary, C., and Davits, It. II. (2000). Competitive exclusion an alternative lo antibiotics. Vet. J., 59: 107-103.

\section{ARABIC SUMMARY}

تأثير اختلاف مصدر ومستوى بعض الإضافات الحيوية العلفية على : ع ـ مناعة وخصائص دم أسماك البلطي النيلى

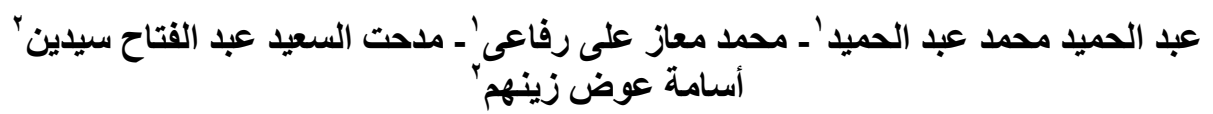

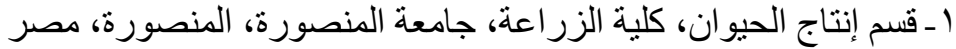

r ـ المعمل المركزى لبحوث الثروة السمكية، مركز البحوث الزية الزر اعبة، العباسة، أبو حماد، مصر

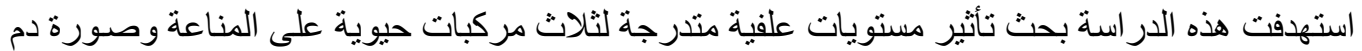

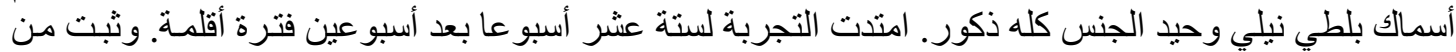

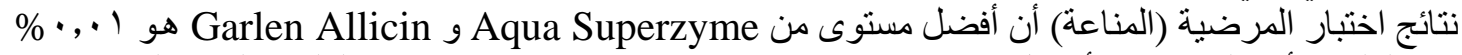

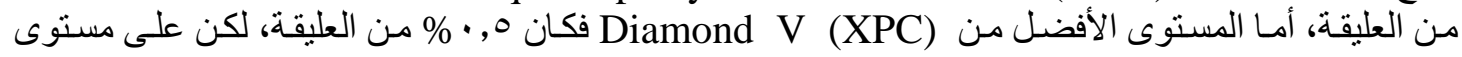

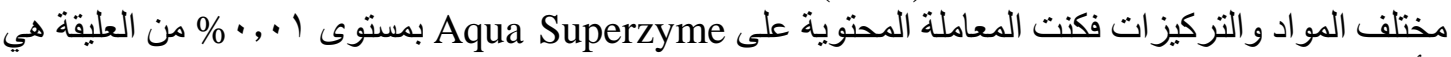

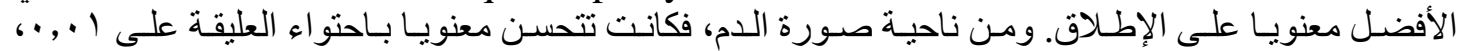

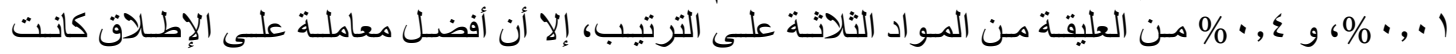

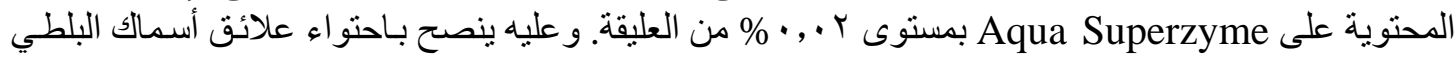

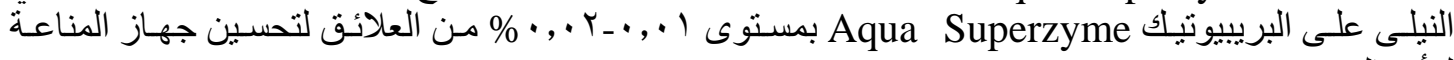

